\title{
PENGARUH MAKROPRUDENSIAL DAN MIKROPRUDENSIAL TERHADAP HARGA SAHAM
}

\author{
Oktoviana Banda Saputri \\ Universitas Indonesia, Indonesia
}

$\triangle$ Corresponding Author:

Nama Penulis: Oktoviana Banda Saputri

E-mail: oktoviana.banda@ui.ac.id

\section{Abstract}

The existence of islamic banking in Indonesia still not as advanced he spirit of Islamic economic life significantly. Based on Indonesia Stock Exchange data, PT Bank Panin Dubai Syariah, Tbk (PNBS) has the first islamic banking to register on the stock exchange on January 15, 2014. This reasearch's aim to analyze indicators that have a greater effect on changes in stock price index. There are six independent variables that are predicted to affect the PNBS stock price. Based on the macro indicators of inflation, exchange rate and BI 7 day repo rate, while micro indicators consist of total assets, DPK growth and the amount of profit (loss). Data collection using secondary data obtained from several sources. By using time series regression analysis followed by the ARCH model, while in the short term testing using the ECM method. Based on results, short term output is closer to theory and hypothesis compared to longterm testing and microprudential have a greater effect on the PNBS stock price index than macroprudential. This study provides recommendations that improving financial performance is very important for the islamic banking industry.

Key words : Islamic Banking; Macroprudential; Microprudential

\section{Abstrak}

Eksistensi perbankan syariah di Indonesia belum mampu membangkitkan semangat kehidupan ekonomi syariah secara signifikan. Berdasarkan data Indonesia Stock Exchange (IDX), PT Bank Panin Dubai Syariah, Tbk (PNBS) merupakan bank syariah pertama yang mendaftarkan perusahaannya pada bursa tanggal 15 Januari 2014. Penelitian ini bertujuan untuk menganalisis indikator yang berpengaruh lebih besar terhadap perubahan indeks harga saham. Terdapat enam variabel bebas yang diprediksi mempengaruhi indeks harga saham PNBS, yaitu dari aspek makro berupa tingkat inflasi, nilai kurs IDR-USD dan BI 7 day repo rate sedangkan dari sisi aspek mikro berupa total aset, pertumbuhan DPK dan besarnya nilai laba (rugi). Metode pengumpulan data menggunakan data sekunder yang diperoleh dari beberapa sumber. Dengan menggunakan analisis regresi time series dinamis dilanjutkan dengan model ARCH, sedangkan dalam pengujian jangka pendek menggunakan metode ECM. Berdasarkan hasil pengujian, output jangka pendek lebih mendekati teori dan hipotesis dibandingkan dengan pengujian jangka panjang dan mikroprudensial berpengaruh lebih besar terhadap indeks harga saham PNBS dibandingkan makroprudensial. Penelitian ini memberikan rekomendasi bahwa meningkatkan kinerja keuangan sangat penting dilakukan bagi industri perbankan syariah.

Kata kunci: Bank Syariah; Makroprudensial; Mikroprudensial 


\section{PENDAHULUAN}

Eksistensi perbankan syariah di Indonesia masih belum semaju negara tetangga seperti Malaysia. Dari awal keberadaannya yang ditandai dengan pendirian PT Bank Muamalat Indonesia, Tbk. (BMI) yang resmi beroperasi pada tahun 1992, belum dapat membangkitkan semangat kehidupan ekonomi syariah secara signifikan di Indonesia. Hal ini tercermin berdasarkan data Otoritas Jasa Keuangan (OJK) pada posisi April 2020, bahwa market share perbankan syariah terhadap total perbankan hanya sebesar 6,07\%. Dilihat dari sejak keberadaan perbankan syariah pertama (28 tahun yang lalu), tentunya hal ini bukan pencapaian yang optimal. Tolak ukur kinerja BMI sulit untuk diproyeksi mengingat sampai dengan saat ini BMI belum terdaftar di Bursa Efek Indonesia (BEI) sebagai salah satu emiten, karena alasan internal perusahaan. Meskipun BMI merupakan perusahaan terbuka, namun sahamnya tidak diperdagangkan di dalam bursa.

Berdasarkan data Otoritas Jasa Keuangan (OJK) sampai dengan posisi Februari 2020, jumlah bank syariah di Indonesia telah tercatat sebanyak 14 Bank Umum Syariah (BUS) dan 34 masih berbentuk Unit Usaha Syariah (UUS). Dari keseluruhan total tersebut, hanya 10 bank syariah yang telah terdaftar di BEI terdiri dari tujuh UUS (karena bank konvensional induknya telah menjadi emiten di bursa) dan tiga BUS yaitu PT Bank Panin Dubai Syariah, Tbk (PNBS), PT Bank BRI Syariah, Tbk (sejak 9 Mei 2018) dan PT Bank Tabungan Pensiunan Nasional Syariah, Tbk (sejak 8 Mei 2018).

Berdasarkan data Indonesia Stock Exchange (IDX), PNBS merupakan bank syariah pertama yang mendaftarkan perusahaannya pada bursa pada tanggal 15 Januari 2014 dan menjadi BUS pertama yang tercatat di BEI. Dengan pendaftaran tersebut, performa PNBS tidak hanya dipengaruhi oleh faktor internal perusahaan tetapi juga akan sangat dipengaruhi oleh indikator eksternal atau kondisi makroekonomi. Dengan masuk ke dalam bursa, PNBS memiliki keuntungan utama yaitu memiliki akses lebih banyak untuk meningkatkan permodalan sehingga dapat meningkatkan produktifitas keuangan melalui penerbitan saham.

Sejak pertama kali PNBS terdaftar di BEI menunjukkan performa yang baik, seiring dengan perkembangan industri keuangan syariah di Indonesia. Berdasarkan pengumuman di BEI, PT Pefindo memberikan peringkat idA+ dengan outlook stabil terhadap PNBS untuk periode Agustus 2020 s.d. Agustus 2021. Peringkat tersebut diberikan berdasarkan data dan informasi bahwa PNBS kinerja tahun-tahun sebelumnya sampai dengan tahun 2019. Meskipun dari sisi harga saham PNBS tidak mengalami tren meningkat (cenderung stabil), namun penguatan terhadap rasio keuangan internal cukup baik. Iklim makroprudensial Indonesia yang kondusif berpengaruh terhadap kondisi keuangan internal PNBS. Gejolak ekonomi yang terjadi di 
sisi makro akan sangat berdampak, baik secara langsung maupun tidak langsung terhadap indeks harga saham PNBS. Begitu pula dengan indikator internal perusahaan dinilai sangat berpengaruh besar terhadap keputusan investor maupun calon investor untuk melakukan aksi di bursa (jual atau beli saham PNBS). Isu ini menjadi sangat menarik untuk diteliti, dengan berkembangnya isu makroprudensial yang baru-baru ini terjadi misalnya kondisi pandemi Covid-19.

Terdapat enam indikator makroprudensial dalam perekonomian konvensional yaitu besarnya Produk Domestik Bruto (PDB), tingkat pengangguran, inflasi, tingkat suku bunga (yang diterbitkan oleh bank sentral), indeks harga saham gabungan, dan nilai tukar. Penelitian ini hanya akan menganalisis tiga dari enam indikator makro ekonomi terhadap performa harga saham PNBS. Indikator ekonomi makro tersebut akan selalu ada sebagai cerminan kondisi suatu negara, namun apabila terjadi resesi/krisis (salah satu contoh fenomena adalah adanya Covid 19), maka indikator ekonomi tersebut diproyeksikan akan menurun/memburuk. Penelitian ini ingin menganalisis performa harga saham PNBS ketika situasi makro baik dan ketika situasi makro menjadi buruk (terlebih adanya fenomena pandemi Covid 19).

Pasar modal syariah adalah seluruh kegiatan di pasar modal yang tidak bertentangan dengan nilai-nilai Islam. Pasar modal syariah merupakan bagian dari industri keuangan syariah yang diatur oleh regulator (0JK), khususnya direktorat pasar modal syariah melalui jual beli saham syariah. Saham syariah merupakan instrumen investasi yang menyatakan bukti penyertaan kepemilikan dalam perusahaan sesuai syariah. Tingkat imbal hasil yang tinggi dalam mekanisme investasi saham, disertai dengan tingkat risiko yang besar pula (high risk and high return). Hal ini menyebabkan faktor keterbukaan informasi merupakan hal penting bagi pengambilan keputusan investor atau calon investor terhadap saham yang terdaftar di bursa.

Penelitian ini bertujuan untuk mengetahui pengaruh indikator makroprudensial dan mikroprudensial terhadap indeks harga saham PNBS. Faktor makroprudensial yang menjadi variabel bebas adalah tingkat inflasi, nilai tukar Rupiah terhadap Dolar Amerika Serikat (USD) dan tingkat suku bunga Bank Indonesia (BI) yang direpresentasikan dengan BI 7 days Repo Rate yang baru diterapkan pada bulan Agustus 2016. Variabel tersebut dikategorikan sebagai kebijakan makroprudensial karena variabel tersebut merupakan kebijakan utama yang diterbitkan oleh bank sentral sebagai regulator makroekonomi dan dianggap variabel yang paling dapat memberikan dampak langsung terhadap harga saham bagi PNBS. Sedangkan indikator makroprudensial lain (PDB, tingkat pengangguran dan tingkat IHSG), kurang mampu memberikan dampak secara langsung terhadap harga 
saham, terutama bagi PNBS. Dari sisi mikroprudensial, penelitian ini ingin mengetahui pengaruh indikator yang berasal dari kondisi internal keuangan perusahaan yang direpresentasikan oleh total aset, tingkat pertumbuhan Dana Pihak Ketiga (DPK), dan besarnya laba berjalan. Besarnya laba berjalan merupakan variabel yang dapat menjadi tolak ukur performa kinerja keuangan suatu entitas yang tercermin dari Laporan Laba/Rugi. Sedangkan, Aset dan pertumbuhan DPK sebagai variabel di dalam Neraca yang komposisi sangat besar dibandingkan dengan variabel lain di dalam pos Neraca.

\section{KAJIAN PUSTAKA}

PT Bank Panin Dubai Syariah, Tbk. (PNBS) merupakan salah bank syariah yang berkantor pusat di Jakarta. Awal pendiriannya merupakan konversi dari PT Bank Harfa setelah diakuisisi oleh PT Bank Panin, Tbk pada tahun 2007. PNBS memperoleh izin usaha dari BI berdasarkan SK GBI No.11/52/KEP.GBI/DpG/2009 tanggal 6 Oktober 2009 sebagai bank umum berdasarkan prinsip syariah dan mulai beroperasi sebagai BUS pada tanggal 2 Desember 2009. Sesuai dengan Anggaran Dasar, ruang lingkup kegiatan usaha PNBS adalah menjalankan kegiatan usaha di bidang perbankan dengan prinsip bagi hasil berdasarkan syariat Islam. Struktur kepemilikan saham PNBS tercantum pada Tabel 1.

Di periode awal pendiriannya, PNBS mengandalkan segmen korporasi dan komersial sebagai sektor utama penggerak pertumbuhan bisnis. Akan tetapi, sejak tahun 2017 hingga saat ini, PNBS memulai transformasi core business yang baru, yaitu fokus dalam menggarap segmen ritel, hal ini juga dipengaruhi oleh pemegang saham baru PNBS yaitu Dubai Islamic Bank yang bergabung sejak tanggal 19 Mei 2014, dengan porsi kepemilikan saham perdana pada saat pertama kali bergabung sebagai pemegang saham PNBS sebesar $24,9 \%$.

Secara teori, tingkat inflasi dan BI 7 day repo rate memiliki pengaruh negatif terhadap indeks harga saham. Hal ini tercermin dengan adanya kondisi naiknya tingkat inflasi dan tingkat suku bunga BI menyebabkan turunnya tren harga saham perusahaan karena investor cenderung menginvestasikan dananya pada instrumen lain dengan suku bunga yang memberikan imbal hasil yang lebih tinggi.

Tabel 1. Kepemilikan Saham PNBS posisi 31 Desember 2019

\begin{tabular}{cc}
\hline Pemegang Saham & Proporsi Kepemilikan \\
\hline PT Bank Panin, Tbk & $53,70 \%$ \\
Dubai Islamic Bank & $38,25 \%$ \\
Masyarakat (Publik) & $8,05 \%$ \\
\hline
\end{tabular}

Sumber : www.paninbanksyariah.co.id(2020) 
Sedangkan, secara teori nilai tukar Rupiah memiliki korelasi positif dengan harga saham perusahaan, apabila nilai tukar Rupiah yang mengalami depresiasi (melemah), maka tingkat keuntungan perusahaan dinilai turun yang mengakibatkan menurun pula tingkat harga saham.

Industri perbankan dikenal sebagai industri yang highly regulated. Sebagai salah satu entitas di industri perbankan syariah, indeks harga saham PNBS juga sangat dipengaruhi oleh indikator kinerja internalnya. Aspek mikroprudensial ini sangat erat kaitannya dengan kondisi keuangan suatu bank sehingga menjadi salah satu Early Warning System (EWS) bagi regulator untuk memantau perkembangan bisnis dan tingkat kesehatan entitas perbankan.

Tabel 2. Review Peneliti Sebelumnya

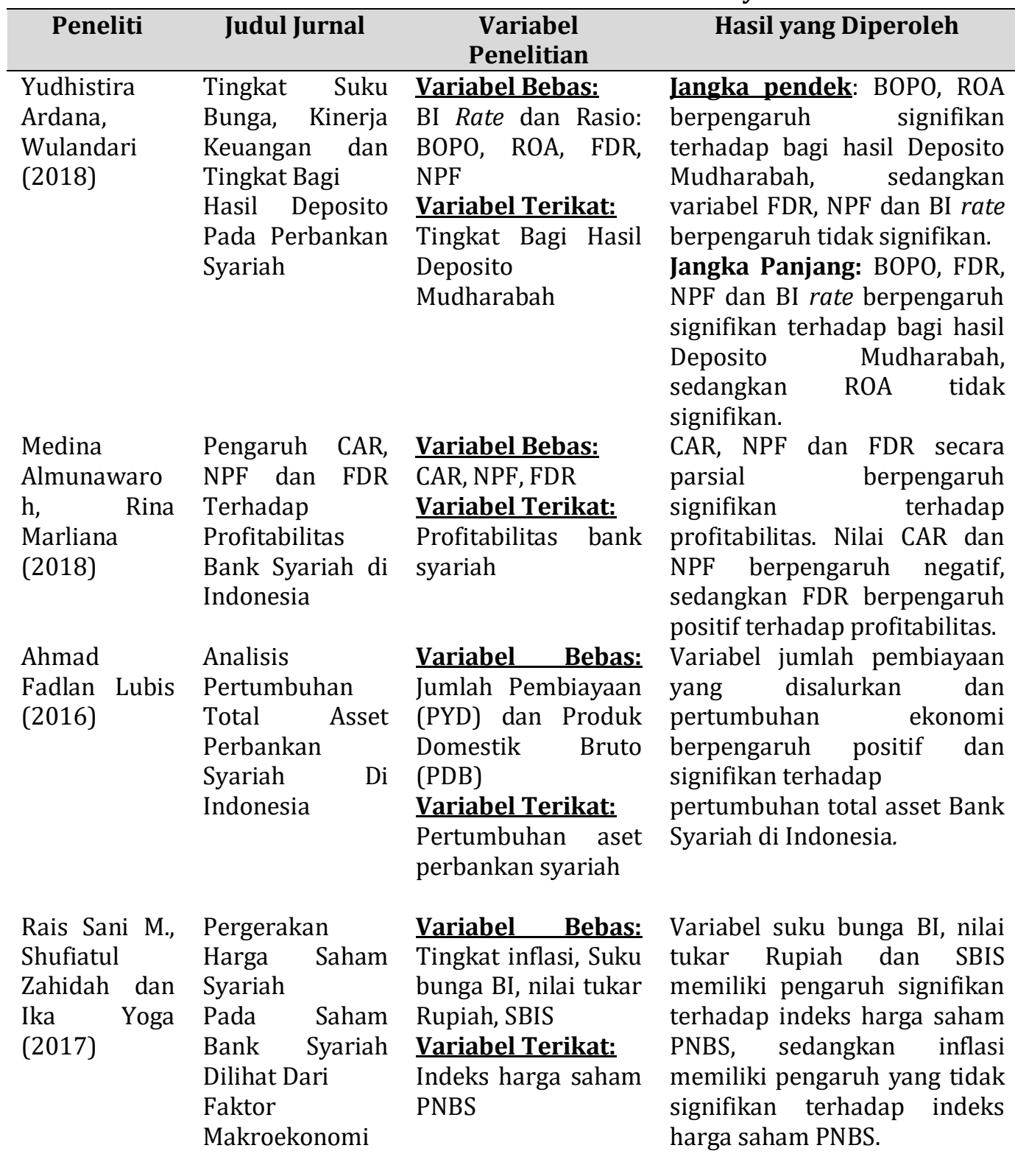

Sumber: Hasil Olahan (2020) 
Dalam penelitian ini, total Aset, tingkat pertumbuhan DPK dan Nilai Laba digunakan sebagai indikator utama kinerja keuangan internal bank yang mampu menjadi salah satu tolak ukur. Secara teori, seluruh peningkatan terhadap variabel tersebut berkorelasi positif terhadap kenaikan indeks harga saham suatu bank.

Kerangka penelitian ini beranjak dari penelitian sebelumnya terkait dengan faktor-faktor yang mempengaruhi kinerja keuangan perbankan syariah. Namun demikian, pada umumnya penelitian tersebut hanya bersifat parsial, yaitu hanya melakukan peninjauan dari sisi internal atau dari sisi eksternal perusahaan saja (kurang komprehensif). Penelitian ini ingin mengintegrasikan pengaruh aspek makroprudensial dengan mikroprudensial terhadap kinerja keuangan, yang masih jarang ditemukan.

Dengan latar belakang teori dan berdasarkan hasil penelitian sebelumnya, hipotesis yang ingin dibangun adalah sebagai berikut:

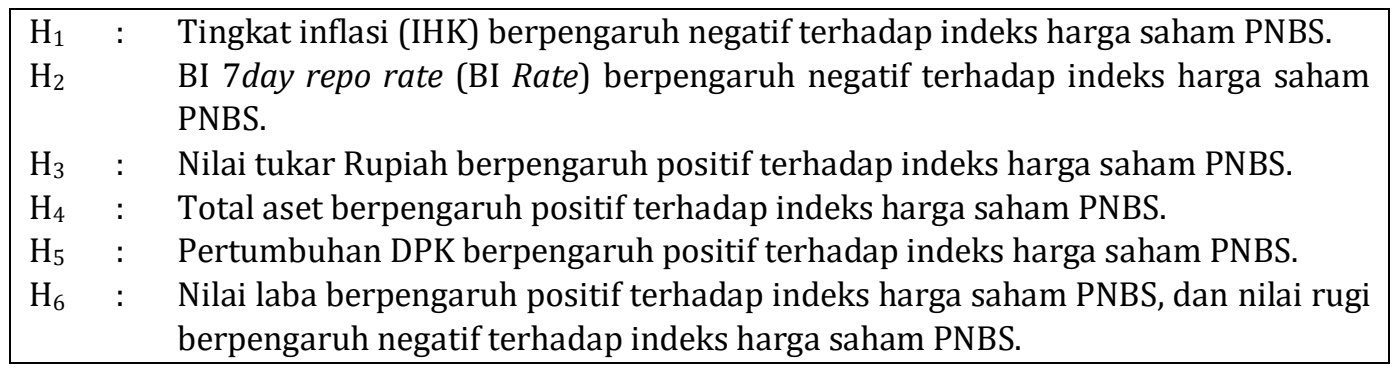

\section{METODE PENELITIAN}

Penelitian ini merupakan penelitian deskriptif kuantitatif yang menekankan pada hubungan yang bersifat sebab akibat (kausalitas). Jenis data yang digunakan dalam penelitian ini adalah data sekunder. Data sekunder merupakan data yang diperoleh secara tidak langsung misalnya melalui sumber dokumentasi. Teknik pengumpulan data menggunakan teknik dokumentasi yang dilakukan yaitu berupa pencarian data laporan indeks harga saham PNBS yang diperoleh dari situs www.idx.co.id. Indikator kinerja keuangan berupa total aset, pertumbuhan DPK dan nilai laba (rugi) diperoleh dari laporan keuangan bulanan publikasi PNBS pada situs www.paninbanksyariah.co.id. Untuk data makroprudensial yang digunakan yaitu tingkat inflasi, BI 7day repo rate, dan nilai tukar Rupiah diperoleh dari laporan publikasi BI melalui situs www.bi.go.id.

Semua data variabel penelitian menggunakan data bulanan mulai periode bulan Agustus 2016 - April 2020, sehingga diperoleh data sebanyak 45 periode. Salah satu pertimbangan pengambilan periode awal penelitian adalah data bulan Agustus 2016, karena pada bulan tersebut BI mengganti 
suku bunga acuan, yang semula BI rate menjadi BI 7 day repo rate. Hal tersebut dilakukan oleh bank sentral dikarenakan instrumen BI 7 days repo rate sebagai acuan yang baru memiliki hubungan yang lebih kuat ke suku bunga pasar uang, sifatnya transaksional atau diperdagangkan di pasar, dan mendorong pendalaman pasar keuangan. Nilai tukar referensi yang digunakan adalah nilai JISDOR (Jakarta Interbank Spot Dollar Rate)yaitu harga transaksi spot USD dengan IDR yang disusun berdasarkan kurs transaksi USD terhadap IDR antar bank di pasar valuta asing Indonesia yang dipantau secara real time oleh BI. Pada Tabel 3 dijelaskan mengenai definisi operasional variabel di dalam penelitian ini, yaitu:

Tabel 3. Definisi Operasional Variabel

Definisi Variabel

Ukuran

\begin{tabular}{|c|c|c|c|}
\hline \multicolumn{2}{|c|}{$\begin{array}{l}\text { Variabel Terikat: } \\
\text { Indeks harga saham PNBS }\end{array}$} & $\begin{array}{l}\text { Indeks harga saham adalah indikator } \\
\text { yang dapat digunakan oleh investor } \\
\text { untuk mengetahui pergerakan pasar } \\
\text { bursa (Rais, 2017). }\end{array}$ & Satuan Rp \\
\hline \multirow{3}{*}{$\begin{array}{l}\text { Variabel } \\
\text { Bebas } \\
\text { Indikator } \\
\text { Makro } \\
\text { prudensial }\end{array}$} & $\begin{array}{l}\text { Tingkat Inflasi = } \\
\text { Indeks } \quad \text { Harga } \\
\text { Konsumen (IHK) }\end{array}$ & $\begin{array}{l}\text { Rasio tingkat harga barang dan jasa } \\
\text { secara umum dan terus menerus } \\
\text { dalam kurun waktu tertentu pada } \\
\text { suatu wilayah. }\end{array}$ & $\%$ \\
\hline & BI 7days repo rate & $\begin{array}{l}\text { Rasio tingkat suku bunga kebijakan } \\
\text { yang dikeluarkan oleh BI dalam } \\
\text { rangka penguatan kerangka operasi } \\
\text { moneter. }\end{array}$ & $\%$ \\
\hline & Kurs & $\begin{array}{l}\text { Harga pertukaran dari satu mata uang } \\
\text { suatu negara dengan mata uang yang } \\
\text { lainnya yang menjadi acuan (baseline). }\end{array}$ & Satuan Rp \\
\hline \multirow{3}{*}{$\begin{array}{l}\text { Variabel } \\
\text { Bebas } \\
\text { Indikator } \\
\text { Mikro } \\
\text { prudensial }\end{array}$} & Aset & $\begin{array}{l}\text { Jumlah harta yang dimiliki dan } \\
\text { dilaporkan oleh bank syariah untuk } \\
\text { mendukung kegiatan operasioanal } \\
\text { perusahaan, diukur dari jumlah aset } \\
\text { terakhir yang sudah dilaporkan } \\
\text { kepada otoritas (Ahmad, 2016). }\end{array}$ & Jutaan Rp \\
\hline & Pertumbuhan DPK & $\begin{array}{l}\text { Rasio perubahan (kenaikan atau } \\
\text { penurunan) DPK yang terdiri dari giro } \\
\text { dan tabungan wadiah serta tabungan } \\
\text { dan deposito mudhorabah. }\end{array}$ & $\%$ \\
\hline & Laba (Rugi) & $\begin{array}{l}\text { Nilai laba atau rugi (setelah dikurangi } \\
\text { pajak) yang tercatat pada bulan } \\
\text { berjalan. }\end{array}$ & Jutaan Rp \\
\hline
\end{tabular}

Sumber : Hasil Olahan (2020)

Teknik analisis data yang digunakan dalam penelitian ini adalah analisis regresi time series dinamis dengan tujuan untuk mengetahui seberapa besar pengaruh variabel bebas terhadap variabel terikat. Urutan teknik analisis data yang digunakan yaitu melakukan pengujian koefisien determinasi, uji asumsi klasik, analisis regresi linier berganda dengan menggunakan model Autoregressive Conditional Heteroscedasticity (ARCH) untuk memperoleh model terbaik. Uji asumsi klasik terdiri dari uji autokorelasi, uji 
multikolinieritas, uji heteroskedastisitas. Alat analisis yang digunakan untuk melakukan pengujian dalam penelitian ini adalah aplikasi Eviews 10.

Setelah dilakukan pengujian asumsi klasik, apabila terjadi korelasi diantara variabel, terbukti adanya multikolinieritas dan heteroskedasitas, maka perlu diatasi untuk dapat memperoleh model yang baik dalam menjelaskan kondisi yang sebenarnya. Selain itu, juga dilakukan pengujian kointegrasi untuk membuktikan korelasi yang terjadi bukan merupakan regresi palsu. Apabila dalam pengujian kointegrasi dapat dibuktikan bahwa regresi yang terjadi bukan merupakan regresi palsu melainkan terjadi kointegrasi diantara variabel, maka pengujian dilanjutkan dengan Error Correction Mechanism (ECM) untuk mengatasi adanya kesalahan keseimbangan (equilibrium error) dan mengetahui korelasi antar variabel dalam jangka pendek.

\section{HASIL PENELITIAN DAN PEMBAHASAN}

Berdasarkan pengolahan data diketahui bahwa regresi yang dihasilkan memiliki nilai $\mathrm{R}^{2}$ sebesar 0,673 atau 67,3\%. Hasil tersebut dapat disimpulkan bahwa variabel bebas yang bersumber dari indikator makroprudensial dan mikroprudensial memiliki kontribusi menjelaskan variasi variabel terikat sebesar 67,3\%, sedangkan sisanya dijelaskan oleh variabel lain yang tidak diperhitungkan di dalam model. Masing-masing variabel bebas memiliki pengaruh yang signifikan terhadap variabel terikat indeks harga saham PNBS, dengan nilai probabilitas variabel lebih kecil dari $\alpha$ 5\%. Kecuali variabel bebas tingkat inflasi dengan nilai probabilitas variabel lebih besar dari $\alpha 5 \%$, sebagaimana penjelasan pada Tabel 4 .

Tabel 4. Hasil Uji Determinasi

\begin{tabular}{cccl}
\hline $\begin{array}{c}\text { Variabel } \\
\text { Bebas }\end{array}$ & Koefisien & $\begin{array}{c}\text { Nilai } \\
\text { Probabilitas }\end{array}$ & \multicolumn{1}{c}{ Keterangan } \\
\hline IHK & $-7,053235$ & 0,4967 & $\begin{array}{l}\text { Berpengaruh tidak signifikan dan } \\
\text { negatif }\end{array}$ \\
\hline Kurs & $-0,032782$ & 0,0001 & Berpengaruh signifikan dan negatif \\
\hline BI Rate & $-18,68865$ & 0,0270 & Berpengaruh signifikan dan negatif \\
\hline Aset & $-0,000019$ & 0,0001 & Berpengaruh signifikan dan negatif \\
\hline DPK & 160,3420 & 0,0307 & Berpengaruh signifikan dan positif \\
\hline Laba & 0,000283 & 0,0065 & Berpengaruh signifikan dan positif \\
\hline C & 827,4123 & 0,0000 & - \\
\hline
\end{tabular}

Sumber : Hasil Olahan(2020)

Persamaan yang dibentuk adalah :

Saham $_{\mathrm{t}}=827,412-7,053235 \mathrm{IHK}_{\mathrm{t}}-0,032782$ Kurs $_{\mathrm{t}}-18,68865$ BIrate $_{\mathrm{t}}-$ 0,000019 Aset $_{t}+160,3420 \mathrm{DPK}_{\mathrm{t}}+0,000283 \mathrm{Laba}_{\mathrm{t}}$ 
Pada output juga diperoleh nilai Akaike Information Criterion (AIC) sebesar 9,349679 dan Schwarz Information Criterion (SIC) sebesar 9,630715. Pada output juga diperoleh nilai statistik Durbin-Watson sebesar 0,652158 (relatif kecil), hal ini menunjukkan bahwa persamaan regresi yang terbentuk masih mengandung otokorelasi positif, pengujian lebih lanjut dapat dilakukan pada saat uji asumsi klasik.

\section{Uji Asumsi Klasik}

a. Uji Otokorelasi dengan menggunakan Lagrange Multiplier-LM (The Breusch-Godfrey Test), diperoleh hasil pengolahan sesuai pada Tabel 5.

Tabel 5. Hasil Uji Otokorelasi

\begin{tabular}{cccc}
\hline F-Statistic & 11,19637 & Prob. $\mathbf{F}(\mathbf{2}, \mathbf{3 6})$ & 0,0002 \\
Obs $^{*}$ R-squared & 17,25682 & $\begin{array}{c}\text { Prob. Chi-Square } \\
\text { (2) }\end{array}$ & 0,0002 \\
\hline
\end{tabular}

\section{Sumber: Hasil Olahan (2020)}

Dengan hipotesis:

$\mathrm{H}_{0}$ : Tidak ada otokorelasi

$\mathrm{H}_{1}$ : Ada otokorelasi

Berdasarkan output di atas, diperoleh nilai probabilitas Obs* Chi Square sebesar 0,0002 < $\alpha 5 \%$, maka keputusan yang diambil adalah menolak $\mathrm{H}_{0}$. Disimpulkan terdapat otokorelasi di dalam model regresi, sehingga harus diatasi untuk mendapatkan model regresi terbaik.

Uji Multikolinieritas dengan menggunakan Variance Inflation Factors (VIF), diperoleh hasil pengolahan data sesuai pada Tabel 6. Dari hasil output diperoleh nilai VIF untuk variabel bebas: $1<$ nilai VIF $<5$, sehingga dapat disimpulkan bahwa tidak terjadi multikolinieritas diantara variabel bebas di dalam model regresi.

Tabel 6. Hasil Uji Multikolonieritas

\begin{tabular}{cc}
\hline Variabel Bebas & Nilai VIF \\
\hline IHK & 1,495607 \\
\hline Kurs & 1,714308 \\
\hline BI Rate & 1,851290 \\
\hline Aset & 1,321538 \\
\hline DPK & 1,151252 \\
\hline Laba & 1,244198
\end{tabular}

Sumber: Hasil Olahan (2020)

b. Uji Heteroskedasitas dengan menggunakan Uji White, diperoleh hasil pengolahan data sesuai pada Tabel 7 yaitu probabilitas Obs*Chi Square sebesar 0,0564 > $\alpha$ 5\%, maka keputusan yang diambil adalah terima $\mathrm{H}_{0}$. Dapat disimpulkan bahwa tidak terdapat heteroskedasitas di dalam model regresi (homokedasitas). 
Oktoviana Banda Saputri: Pengaruh Makroprudensial dan Mikroprudensial

\begin{tabular}{cclc}
\hline \multicolumn{4}{c}{ Tabel 7. Hasil Uji Heteroskedasitas } \\
\hline F-Statistic & 4,566605 & Prob. F(27,17) & 0,0010 \\
Obs $^{*}$ R-squared & 39,54733 & Prob. Chi-Square (27) & 0,0564 \\
Scaled explained SS & 40,41475 & Prob. Chi-Square (27) & 0,0468 \\
\hline
\end{tabular}

Sumber: Hasil Olahan (2020)

Dengan hipotesis:

$\mathrm{H}_{0}$ : Homokedasitas

$\mathrm{H}_{1}$ : Heteroskedasitas

\section{Uji Stasioneritas -Uji Unit Root}

Dengan melakukan uji stasioneritas dapat mengatasi permasalahan otokorelasi yang terjadi, sebagaimana hasil pengolahan pada Tabel 5 bahwa persamaan yang dibentuk terdapat otokorelasi yang terjadi. Uji stasioneritas dilakukan dengan menggunakan Augmented Dickey-Fuller (ADF) Test, diperoleh hasil pada Tabel 8.

Sebagai acuan:

ADFt-statistik >t-critical MacKinnon = memiliki akar unit atau tidak stasioner

ADFt-statistik <t-critical MacKinnon = tidak memiliki akar unit atau stasioner

Berdasarkan output pengolahan pada Tabel 8, diperoleh variabel indeks harga saham PNBS, pertumbuhan DPK dan nilai laba telah stasioner pada level nol atau pada ordo (0), sedangkan variabel tingkat inflasi, nilai kurs, BI 7day repo rate, dan total aset stasioner pada level pertama (first difference) atau ordo (1).

Tabel 8. Hasil Uji Stasioneritas

\begin{tabular}{|c|c|c|c|c|c|c|}
\hline \multirow{2}{*}{ Variabel } & \multirow{2}{*}{$\begin{array}{l}\text { ADF t- } \\
\text { statistik }\end{array}$} & \multirow{2}{*}{$\begin{array}{l}\text { Nilai } \\
\text { Probabi } \\
\text { litas }\end{array}$} & \multicolumn{3}{|c|}{ Nilai Kritis MacKinnon } & \multirow{2}{*}{$\begin{array}{c}\text { Keterangan } \\
\text { Stasionerit } \\
\text { as }\end{array}$} \\
\hline & & & $1 \%$ & $5 \%$ & $10 \%$ & \\
\hline Saham & $-4,186414$ & 0,0019 & $-3,588509$ & $-2,929734$ & $-2,603064$ & Ordo (0) \\
\hline IHK & $-6,568314$ & 0,0000 & $-3,592462$ & $-2,931404$ & $-2,603944$ & Ordo (1) \\
\hline Kurs & $-4,404602$ & 0,0010 & $-3,592462$ & $-2,931404$ & $-2,603944$ & Ordo (1) \\
\hline BI Rate & $-3,696210$ & 0,0076 & $-3,592462$ & $-2,931404$ & $-2,603944$ & Ordo (1) \\
\hline Aset & $-7,950761$ & 0,0000 & $-3,592462$ & $-2,931404$ & $-2,603944$ & Ordo (1) \\
\hline DPK & $-8,615245$ & 0,0000 & $-3,588509$ & $-2,929734$ & $-2,603064$ & Ordo (0) \\
\hline Laba & $-4,650524$ & 0,0005 & $-3,592462$ & $-2,931404$ & $-2,603944$ & Ordo (0) \\
\hline
\end{tabular}

Sumber: Hasil Olahan (2020)

Dengan hipotesis:

$\mathrm{H}_{0} \quad: \delta=0$ (data tidak stasioner)

$\mathrm{H}_{1} \quad: \delta \neq 0$ (data stasioner) 
Oktoviana Banda Saputri: Pengaruh Makroprudensial dan Mikroprudensial

\section{Model ARCH (Autoregressive Conditional Heteroscedasticity)}

Dalam rangka memperoleh model terbaik, pengolahan data lebih lanjut menggunakan model ARCH dengan menggunakan pembedaan umum (Generalized Differences), diperoleh hasil pengolahan pada Tabel 9.

Tabel 9. Hasil Uji Model ARCH

\begin{tabular}{cccl}
\hline $\begin{array}{c}\text { Variabel } \\
\text { Bebas }\end{array}$ & Koefisien & $\begin{array}{c}\text { Nilai } \\
\text { Probabilitas }\end{array}$ & \multicolumn{1}{c}{ Keterangan } \\
\hline IHK & 5,101687 & 0,4338 & Berpengaruh tidak signifikan dan positif \\
\hline Kurs & $-0,003893$ & 0,4581 & Berpengaruh tidak signifikan dan negatif \\
\hline BI Rate & $-0,162790$ & 0,9839 & Berpengaruh tidak signifikan dan negatif \\
\hline Aset & $-0,000012$ & 0,8223 & Berpengaruh tidak signifikan dan negatif \\
\hline DPK & 25,50810 & 0,1388 & Berpengaruh tidak signifikan dan positif \\
\hline Laba & 0,0000504 & 0,1017 & Berpengaruh tidak signifikan dan positif \\
\hline C & 83,83553 & 0,1018 & - \\
\hline AR(1) & 0,818900 & 0,0000 & Berpengaruh signifikan dan positif \\
\hline
\end{tabular}

Sumber: Hasil Olahan (2020)

Berdasarkan pengolahan data pada Tabel 9, diketahui bahwa regresi yang dihasilkan memiliki nilai $\mathrm{R}^{2}$ sebesar 0,9373 atau 93,73\% (paling tinggi). Hasil tersebut dapat disimpulkan bahwa variabel bebas yang bersumber dari indikator makroprudensial dan mikroprudensial memiliki kontribusi menjelaskan variasi variabel terikat sebesar 93,73\%, sedangkan sisanya dijelaskan oleh variabel lain yang tidak diperhitungkan di dalam model. Masing-masing variabel bebas memiliki pengaruh yang tidak signifikan terhadap variabel terikat indeks harga saham PNBS, dengan nilai probabilitas variabel lebih besar dari $\alpha 5 \%$.

Pada output juga diperoleh nilai Akaike Information Criterion (AIC) sebesar 7,470995 dan Schwarz Information Criterion (SIC) sebesar 7,917043. Pada output juga diperoleh nilai statistik Durbin-Watson sebesar 1,582606 (relatif besar). Hal ini menunjukkan bahwa persamaan regresi yang terbentuk sudah tidak mengandung otokorelasi.

Pada Tabel 9 memperlihatkan bahwa dalam jangka panjang tidak ada variabel (baik mikroprudensial maupun makroprudensial) yang berpengaruh secara signifikan terhadap harga saham PNBS. Variabel IHK, pertumbuhan DPK dan laba memiliki pengaruh positif, sedangkan variabel Kurs, BI Rate dan Aset memiliki pengaruh negatif terhadap harga saham PNBS. Namun demikian, secara bersama-sama variabel IHK, pertumbuhan DPK, Laba, Kurs, BI Rate dan Aset memiliki berpengaruh signifikan dan positif terhadap harga saham PNBS dalam jangka panjang sebagaimana tercermin dari nilai probabilitas AR(1).

\section{Pengujian Kointegrasi}

Berdasarkan pengolahan data pada Tabel 4, diperoleh nilai $\mathrm{R}^{2}$ sebesar 0,673186, nilai statistik Durbin-Watson sebesar sebesar 0,652158. 
Oktoviana Banda Saputri: Pengaruh Makroprudensial dan Mikroprudensial

\begin{tabular}{ccccccc}
\hline \multicolumn{5}{c}{ Tabel 10. Hasil Uji Stasioneritas Residual Variabel } \\
Variabel & $\begin{array}{c}\text { ADF t- } \\
\text { statistik }\end{array}$ & Probabilitas & Nilai & \multicolumn{2}{c}{ Nilai Kritis MacKinnon } & \\
\cline { 3 - 5 } & - & 0,0083 & $-3,588509$ & $-2,929734$ & - & Ordo (0) \\
\hline Ut & - & & & & 2,603064 & \\
\hline
\end{tabular}

Sumber: Hasil Olahan (2020)

Menurut Granger dan Newold, jika $\mathrm{R}^{2}>$ nilai statistik Durbin-Watson, sehingga dapat disimpulkan sementara bahwa hasilnya merupakan regresi palsu. Untuk itu, perlu dibuktikan pengujian kointegrasi untuk memastikan bahwa yang terjadi bukan regresi palsu, melainkan terjadi regresi kointegrasi. Dilakukan uji kointegrasi menggunakan uji Engle-Granger atau uji Augmented Engle-Granger, dengan hipotesis:

$\mathrm{H}_{0} \quad$ : residual model tidak stasioner

$\mathrm{H}_{1} \quad$ : residual model stasioner

Dengan menggunakan uji ADF terhadap series residual $\left(\mathrm{u}_{\mathrm{t}}\right)$ atas variabel terikat dan variabel bebas, diperoleh hasil pengolahan sebagaimana disampaikan pada Tabel 10.

Berdasarkan Tabel 10, series residual $\left(\mathrm{u}_{\mathrm{t}}\right)$ telah stasioner pada ordo 0 atau I(0), dengan nilai $p$-value sebesar 0,0083 < 5\%, sehingga diputuskan untuk menolak $\mathrm{H}_{0}$. Dapat disimpulkan bahwa keenam variabel tersebut terkointegrasi pada ordo 0 yang membuktikan tidak terjadi regresi palsu diantara kedua variabel (bebas dan terikat) melainkan terjadi kointegrasi atau terdapat hubungan jangka panjang.

\section{Error Correction Mechanism (ECM)}

Setelah model telah berhasil lolos uji kointegrasi antara variabel atau telah terbukti terjadi keseimbangan jangka panjang, perlu dilakukan koreksi keseimbangan jangka pendek menuju keseimbangan jangka panjang menggunakan uji ECM untuk mengestimasi model dinamis jangka pendek dari variabel terikat indeks harga saham PNBS, sebagaimana dijelaskan pada Tabel 11.

Berdasarkan pengolahan data diperoleh koefisien determinasi $U_{t}$ signifikan $(0,0007<5 \%)$. Hal ini dapat disimpulkan bahwa variabel terikat (indeks harga saham PNBS) menyesuaikan perubahan variabel bebas (IHK, kurs, BI 7day repo rate, total aset, pertumbuhan DPK dan laba) pada periode yang sama atau penyesuaian dilakukan pada satu periode berikutnya untuk menuju keseimbangan jangka panjang secara signifikan, karena nilai koefisien residualnya cukup besar $28,44 \%$.

Pada Tabel 11 memperlihatkan bahwa dalam jangka pendek, hanya ada satu variabel yang berpengaruh secara signifikan terhadap harga saham PNBS yaitu pertumbuhan DPK, sedangkan variabel lain berpengaruh secara tidak signifikan. 
Oktoviana Banda Saputri: Pengaruh Makroprudensial dan Mikroprudensial

\begin{tabular}{|c|c|c|c|}
\hline \multicolumn{4}{|c|}{ Tabel 11. Hasil Uji ECM } \\
\hline $\begin{array}{c}\text { Variabel } \\
\text { Bebas }\end{array}$ & Koefisien & $\begin{array}{c}\text { Nilai } \\
\text { Probabilitas }\end{array}$ & Keterangan \\
\hline IHK & 1,016049 & 0,8643 & $\begin{array}{l}\text { Perubahan jangka pendek IHK, } \\
\text { berpengaruh tidak signifikan dan positif } \\
\text { pada perubahan jangka pendek harga } \\
\text { saham PNBS }\end{array}$ \\
\hline Kurs & $-0,000239$ & 0,9634 & $\begin{array}{l}\text { Perubahan jangka pendek kurs, } \\
\text { berpengaruh tidak signifikan dan negatif } \\
\text { pada perubahan jangka pendek harga } \\
\text { saham PNBS }\end{array}$ \\
\hline BI Rate & $-8,121959$ & 0,3732 & $\begin{array}{l}\text { Perubahan jangka pendek BI rate, } \\
\text { berpengaruh tidak signifikan dan negatif } \\
\text { pada perubahan jangka pendek harga } \\
\text { saham PNBS }\end{array}$ \\
\hline Aset & $\begin{array}{l}- \\
0,00000003\end{array}$ & 0,9421 & $\begin{array}{l}\text { Perubahan jangka pendek total aset, } \\
\text { berpengaruh tidak signifikan dan negatif } \\
\text { pada perubahan jangka pendek harga } \\
\text { saham PNBS }\end{array}$ \\
\hline DPK & 44,08574 & 0,0307 & $\begin{array}{l}\text { Perubahan jangka pendek pertumbuhan } \\
\text { DPK, berpengaruh signifikan dan positif } \\
\text { pada perubahan jangka pendek harga } \\
\text { saham PNBS }\end{array}$ \\
\hline Laba & 0,000016 & 0,7137 & $\begin{array}{l}\text { Perubahan jangka pendek laba, } \\
\text { berpengaruh tidak signifikan dan positif } \\
\text { pada perubahan jangka pendek saham } \\
\text { PNBS }\end{array}$ \\
\hline Ut & $-0,284383$ & 0,0007 & Berpengaruh signifikan dan negatif \\
\hline
\end{tabular}

\section{Sumber: Hasil Olahan (2020)}

Variabel IHK, pertumbuhan DPK dan laba memiliki pengaruh yang positif terhadap harga saham PNBS, sedangkan variabel kurs, BI rate dan total aset memiliki pengaruh yang negatif terhadap harga saham PNBS. Namun demikian, secara bersama-sama seluruh variabel dalam jangka pendek memiliki pengaruh yang signifikan dan negatif terhadap harga saham PNBS yang ditunjukkan dari nilai probabilitas Ut.

Berdasarkan perhitungan dan analisis, diketahui bahwa variabel IHK dalam jangka pendek dan jangka panjang berpengaruh tidak signifikan dan positif terhadap indeks harga saham PNBS.

Hasil penelitian ini mendukung hasil penelitian sebelumnya yang dilakukan Sani (2017) yang menyatakan bahwa tingkat inflasi (IHK) secara parsial memiliki pengaruh yang tidak signifikan terhadap harga saham. Namun demikian, hasil penelitian ini berbeda dengan teori yang menyatakan bahwa inflasi memiliki hubungan negatif terhadap harga saham. Hal ini tercermin apabila tingkat inflasi tinggi, investor cenderung menginvestasikan dananya pada instrumen lain yang dapat memberikan imbal hasil yang lebih 
tinggi, sehingga secara teori harga saham suatu entitas akan cenderung turun.

Dalam jangka panjang dan pendek, variabel nilai tukar (kurs) memiliki pengaruh yang tidak signifikan dan negatif terhadap indeks harga saham PNBS. Hasil penelitian ini tidak sesuai dengan dugaan hipotesis yang dibangun dan teori yang digunakan yang menyatakan bahwa nilai tukar Rupiah memiliki korelasi positif dengan harga saham perusahaan, karena apabila nilai tukar Rupiah yang mengalami depresiasi (melemah), maka tingkat keuntungan perusahaan juga akan dinilai turun yang mengakibatkan menurun pula tingkat harga saham, begitupula sebaliknya apabila terjadi apresiasi (penguatan mata uang). Hasil penelitian ini mendukung hasil penelitian yang dilakukan oleh Sani (2017) yang menyatakan bahwa nilai tukar memiliki pengaruh negatif terhadap harga saham.

Dalam jangka panjang dan pendek, variabel BI rate memiliki pengaruh tidak signifikan dan negatif terhadap harga saham PNBS. Hasil penelitian ini mendukung hipotesis dan teori yang digunakan yaitu tingkat suku bunga BI memiliki korelasi negatif terhadap harga saham suatu entitas. Kenaikan pada tingkat suku bunga BI, menyebabkan turunnya tren harga saham perusahaan, karena dalam kondisi tersebut investor akan cenderung menginvestasikan dananya pada instrumen keuangan lain yang memiliki tingkat suku bunga yang memberikan imbal hasil lebih tinggi dibandingkan investasi ke dalam saham.

Dalam jangka panjang dan pendek, variabel total aset berpengaruh tidak signifikan dan negatif terhadap harga saham PNBS. Hasil penelitian ini tidak sesuai dengan hasil hipotesis dan teori yang menyatakan bahwa setiap kenaikan total aset berkorelasi positif terhadap kenaikan indeks harga saham suatu perusahaan. Berdasarkan penelitian ini dapat disimpulkan bahwa investor lebih tertarik pada aspek profitabilitas perbankan dibandingkan dengan peningkatan total aset, karena total aset tidak mencerminkan aspek profitabilitas atau keuangan yang akan diterima oleh investor.

Dalam jangka panjang, variabel pertumbuhan DPK memiliki pengaruh tidak signifikan dan positif terhadap harga saham PNBS. Sedangkan dalam jangka pendek, pertumbuhan DPK memiliki pengaruh signifikan dan positif terhadap harga saham PNBS. Hasil penelitian ini mendukung teori dan hipotesis yang menyatakan bahwa setiap kenaikan DPK memiliki korelasi positif terhadap kenaikan harga saham suatu perusahaan. Sebagai salah satu komponen penting dalam laporan keuangan perbankan, pertumbuhan dan kenaikan DPK dapat mengindikasikan bahwa suatu entitas perbankan memiliki tingkat kesehatan yang positif. 
Dalam jangka panjang dan pendek, variabel nilai laba memiliki pengaruh yang tidak signifikan dan positif terhadap harga saham PNBS. Hal ini sesuai dengan teori dan hipotesis yang digunakan, bahwa laba atau tingkat profit memiliki pengaruh dan positif terhadap indeks harga saham suatu entitas. Dengan tingkat profitabilitas dan keuntungan yang tinggi, para investor akan cenderung membeli lebih banyak saham suatu entitas sehingga dapat menyebabkan indeks harga saham perusahaan tersebut akan meningkat.

\section{KESIMPULAN DAN SARAN}

\section{Kesimpulan}

Terdapat enam variabel bebas yang diproyeksikan dapat mempengaruhi indeks harga saham PNBS, yaitu dari indikator makroprudensial berupa tingkat inflasi, nilai tukar (kurs IDR-USD) dan BI 7day repo rate serta indikator mikroprudensial berupa total aset, pertumbuhan DPK dan besarnya nilai laba (rugi). Dengan menggunakan analisis regresi time series dinamis dilanjutkan dengan model ARCH diketahui bahwa berdasarkan pengujian jangka panjang seluruh variabel bebas berpengaruh tidak signifikan terhadap indeks harga saham PNBS, variabel yang positif berpengaruh adalah tingkat inflasi, pertumbuhan DPK dan nilai laba, sedangkan variabel yang berpengaruh negatif terhadap indeks harga saham PNBS yaitu nilai tukar, BI Rate dan total aset.

Dalam pengujian jangka pendek menggunakan metode ECM, diperoleh variabel yang berpengaruh tidak signifikan dan positif yaitu tingkat inflasi dan laba. Untuk variabel yang berpengaruh tidak signifikan dan negatif yaitu nilai kurs, BI Rate dan total aset, sedangkan variabel yang berpengaruh signifikan dan positif adalah pertumbuhan DPK terhadap indeks harga saham PNBS. Hal ini menjelaskan bahwa hasil pengujian jangka pendek lebih mendekati teori dan hipotesis dibandingkan dengan pengujian jangka panjang dan indikator mikroprudensial lebih berpengaruh terhadap indeks harga saham PNBS dibandingkan dengan indikator makroprudensial. Penelitian ini memberikan rekomendasi bahwa transparansi kondisi kinerja keuangan merupakan informasi yang penting dalam fluktuasi perubahan indeks harga saham suatu entitas, dengan tidak mengesampingkan kondisi makroprudensial (ekonomi secara umum).

\section{Saran}

Berdasarkan hasil penelitian ini diperoleh gambaran bahwa indeks harga saham suatu entitas, masih sangat erat kaitannya dengan penilaian aspek mikroprudensial terutama penilaian keuangan bagi entitas perbankan syariah. Share yang belum terlalu besar di bursa menjadikan aspek kinerja 
keuangan internal menjadi unsur utama fluktuasi indeks harga saham bank syariah. Meskipun demikian, penelitian ini masih memiliki beberapa keterbatasan, diantaranya (1) rentang periode pengujian yang dilakukan sejak Agustus 2016, dapat diperbesar dari sejak PNBS masuk ke dalam bursa yaitu pada Mei 2014, (2) variabel independen yang lebih bervariasi terutama dari sisi kinerja keuangan internal bank misalnya dengan menambahkan beberapa indikator rasio keuangan, dan (3) studi kasus terhadap perusahaan yang lebih aktif di bursa, mengingat berdasarkan pemantauan indeks harga saham, PNBS tergolong saham yang kurang aktif di bursa. Diharapkan ke depan terdapat penelitian-penelitian lanjutan dengan rekomendasi sebagaimana saran penelitian ini sehingga mampu memberikan output yang lebih komprehensif.

\section{DAFTAR PUSTAKA}

Almunawwaroh, M, Rina M. (2018). Pengaruh CAR, NPF dan FDR Terhadap Profitabilitas Bank Syariah Di Indonesia. Amwaluna: Jurnal Ekonomi dan Keuangan Syariah, 2 (1), 1 - 18.

Ardana, Y.W. (2018). Tingkat Suku Bunga, Kinerja Keuangan dan Tingkat Bagi Hasil Deposito Pada Perbankan Syariah. Esensi: Jurnal Bisnis dan Manajemen. 8 (2), 177 - 186.

Bank Indonesia. (2020). Statistik Publikasi. Diakses tanggal 20 Mei - 8 Juni 2020, https://www.bi.go.id/.

Bursa Efek Indonesia. (2020). Pasar Modal Syariah Indonesia. Diakses tanggal 20 Mei - 8 Juni 2020, https://www.idx.co.id/.

Elliyawati, W. Y., R. Rustam H., Devi, F. A. (2014). Penerapan Model Garch (Generalized AutoregressiveConditional Heteroscedasticity) Untuk Menguji Pasar Modal Efisien Di Indonesia (Studi pada Harga Penutupan (Closing Price) Indeks Saham LQ 45 Periode 2009-2011). Jurnal Administrasi Bisnis, 7 (2).

Fadlan, A.L. (2016). Analisis Pertumbuhan Total Asset Perbankan Syariah Di Indonesia. Nusantara (Jurnal Ilmu Pengetahuan Sosial), 1.

Marimin, A., Abdul H. R., Tira N. F. (2015). Perkembangan Bank Syariah Di Indonesia. Jurnal Ilmiah Ekonomi Islam, 1 (2).

Mu'arifah, Khusnul, Sam'ani. (2019). Analisis Faktor-Faktor Yang Mempengaruhi Harga Saham Pada Perusahaan Yang Terdaftar Di Jakarta Islamic Index (Jii) Periode 2014-2018. Jurnal Sains Ekonomi dan Perbankan Syariah, 9 (1).

Muhammad, M. (2014). Kointegrasi dan Estimasi ECM pada Data Time Series. Jurnal Konvergensi, 4 (1). 
Nofinawati. (2015). Perkembangan Perbankan Syariah Di Indonesia. Juris, 14 (2).

Otoritas Jasa Keuangan. (2020). Statistik Perbankan Syariah Februari 2020. Diakses tanggal 20 Mei - 8 Juni 2020, https://www.ojk.go.id/.

PT Bank Panin Dubai Syariah, Tbk. (2020). Laporan Keuangan Publikasi. Diakses tanggal 20 Mei - 8 Juni 2020, https://www.paninbanksyariah.co.id/.

Sani, R. M., Shufiatul Z., Ika Y. (2017). Pergerakan Harga Saham Syariah Pada Saham Bank Syariah Dilihat Dari Faktor Makroekonomi. BISNIS, 5 (1).

Soematri. (2016). Penerapan Metode Two Stage Least Squares Pada Model Persamaan Simultan dalam Memprediksi PDRB dan Pertumbuhan Ekonomi. Seminar Nasional Pendidikan Matematika 